\title{
Derivation and Properties of F-prime Factors in Escherichia coli Carrying Nitrogen Fixation Genes from Klebsiella pneumoniae
}

\author{
By F. C. CANNON, R. A. DIXON AND J. R. POSTGATE \\ A.R.C. Unit of Nitrogen Fixation, University of Sussex, Brighton BNI $9 Q J$
}

(Received 3I July 1975)

\begin{abstract}
SUMMARY
A $\mathrm{His}^{+} \mathrm{Nif}^{+}$Escherichia coli $\mathrm{KI}$ 2, Hfr strain (UNF43) was constructed by an intergeneric mating between a Klebsiella pneumoniae donor strain (HF3) and a His-, Hfr E. coli strain (SBI 824) which transfers his as an early marker. An F-prime nif plasmid, FN39, carrying genes which correspond to the $E$. coli chromosomal region, met $G$ gnd his shiA, but excluding purF and aroD, was isolated from UNF43. Translocation of carbenicillin resistance genes from a P-type R-factor, R68, to $\mathrm{FN}_{39}$ increased the stability of his and nif on the derivative F-prime, FN68.

Sedimentation analysis of both F-primes in sucrose gradients revealed four covalently closed circular(CCC) DNA species of molecular weights $279 \pm 9,136 \pm 3$, $90 \pm 1$ and $44 \pm I$ megadaltons. It is suggested that the two smallest CCC-DNA species are component replicons of the composite F-primes of molecular weight $136 \pm 3$ megadaltons, and that the molecules of $279 \pm 9$ megadaltons are CCC-dimers.

FN68 was transferable in intergeneric matings to Klebsiella aerogenes, $K$. pneumoniae and Salmonella typhimurium but not to Proteus mirabilis; only carbenicillin resistance and sex factor activity were transferred to Erwinia herbicola. nif genes on FN68 were expressed in a Nif- mutant of $K$. pneumoniae and also in $S$. typhimurium, which in conventional tests is naturally non-nitrogen-fixing; expression of the his determinant of FN68 became temperature-sensitive in S. typhimurium.
\end{abstract}

\section{INTRODUCTION}

In the enteric bacterium Klebsiella pneumoniae, genes determining nitrogen fixation (nif) are clustered close to the histidine operon (Streicher, Gurney \& Valentine, I97I; Dixon \& Postgate, I97I). Most nif mutations are 30 to $80 \%$ co-transducible with his $D$ on the Klebsiella chromosome, (Streicher, Gurney \& Valentine, 1972). A deletion analysis of the nif region indicates that $n i f$ genes are located between his and shiA in Klebsiella (Shanmugam, Loo \& Valentine, 1974).

nif genes have been transferred from $K$. pneumoniae to Escherichia coli strain c (Dixon \& Postgate, 1972). In a stable hybrid C-M7, nif genes were integrated into the his region of the E. coli chromosome (Cannon et al., 1974 a) while in two less stable hybrids, C-M9 and C-L4, there was evidence that $n i f$ genes were carried on plasmids (Cannon et al., 1974 $b$ ). Although these plasmids were mobilized by $\mathrm{R}$ factors they were not self-transmissible. Sex-factor plasmids containing nif genes would facilitate both diploid analysis and further genetic transfer of nif; a preliminary report of the construction of such F-prime plasmids was presented by Dixon (1974). We describe here the isolation and properties of F-prime factors carrying the nitrogen fixation genes from $K$. pneumoniae. 
Table I. Bacteria, plasmids and bacteriophages

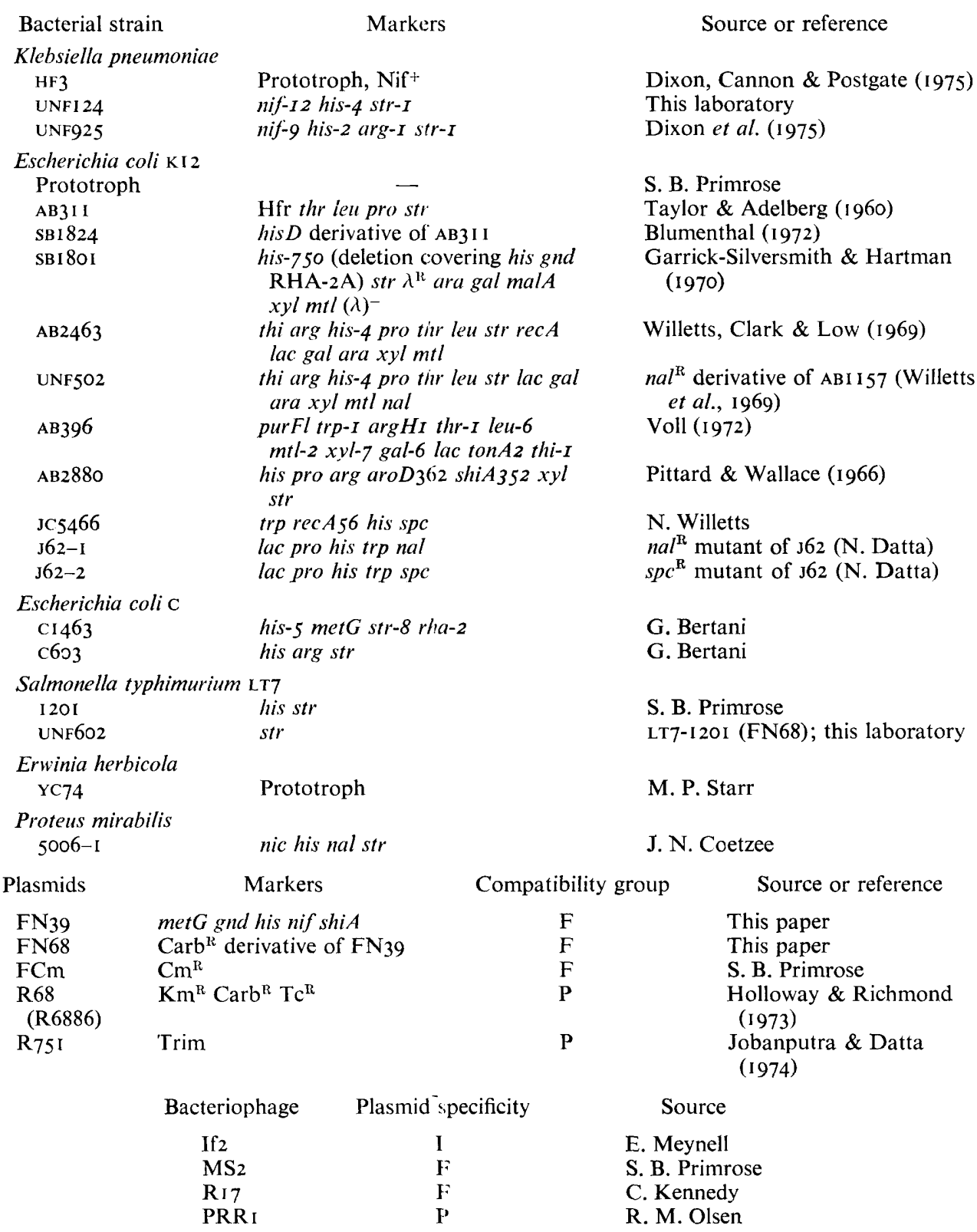

Symbols for drug resistance determinants are: $\mathrm{Km}$, kanamycin; Carb, carbenicillin; Tc, tetracycline; Trim, trimethoprim; Cm, chloramphenicol. Genetic symbols for chromosomal markers are those of Taylor \& Trotter (1972).

\section{METHODS}

Bacterial strains, plasmids and bacteriophages. These are listed in Table I.

Media. Complete medium was nutrient broth (Oxoid No. 2) solidified with $1 \cdot 5 \%$ Davis New Zealand agar. $\mathrm{NH}_{4}{ }^{+}$-free medium was NFDM (Cannon et al., $1974 a$ ) and was solidified 
with $\mathrm{I} \cdot 5 \%$ Serva high gel strength agar. Minimal medium was Davis \& Mingioli (I950) mineral salts. Cultures for DNA isolation were grown in minimal medium $\mathrm{C}$, containing: $\mathrm{K}_{2} \mathrm{HPO}_{4}$ buffer $\mathrm{pH} 7 \cdot 2$, $60 \mathrm{~mm}$; $\left(\mathrm{NH}_{4}\right)_{2} \mathrm{SO}_{4}, 15 \mathrm{~mm}$; $\mathrm{MgSO}_{4} \cdot 7 \mathrm{H}_{2} \mathrm{O}, 0.8 \mathrm{~mm} ; \mathrm{NaCl}, 0.17 \mathrm{~mm}$; $\mathrm{CaCl}_{2} .2 \mathrm{H}_{2} \mathrm{O}, 6 \cdot 8 \mu \mathrm{M}$; glucose, $0.2 \%(\mathrm{w} / \mathrm{v})$. The buffer concentration of this medium was lowered to $20 \mathrm{~mm}$ when cultures were grown for transformation.

Antibiotics. These were added to media as freshly-prepared solutions sterilized by filtration. The following final concentrations $(\mu \mathrm{g} / \mathrm{ml})$ were added to select plasmid-mediated drug resistance in $E$. coli: kanamycin sulphate, 30; tetracycline- $\mathrm{HCl}, \mathrm{I} 5$; carbenicillin, 200; trimethoprim lactate, 50; chloramphenicol, 30. Chromosomal resistance markers were selected at the following final concentrations $(\mu \mathrm{g} / \mathrm{ml})$ : streptomycin, 250 ; spectinomycin I00; nalidixic acid, 25. With Proteus mirabilis, carbenicillin was used at $50 \mu \mathrm{g} / \mathrm{ml}$; with Salmonella typhimurium, carbenicillin was used at $400 \mu \mathrm{g} / \mathrm{ml}$. Carbenicillin was a gift from Beecham Research Laboratories, Brockham Park, Betchworth, Surrey; trimethoprim lactate was kindly supplied by Burroughs Wellcome \& Co., The Wellcome Foundation, Berkhamsted, Hertfordshire, and spectinomycin was a gift from the Upjohn Co., Kalamazoo, Michigan, U.S.A.

Conjugation. For broth matings, donor and recipient were grown overnight in static nutrient broth and then diluted into prewarmed broth and incubated with slow shaking at $37^{\circ} \mathrm{C}$ until donor cultures contained about $2 \times 10^{8}$ bacteria $/ \mathrm{ml}$ and recipient cultures about $5 \times 10^{8}$ bacteria/ml. Cultures were mixed at a donor-recipient ratio of I : 10 (I: I for intergeneric matings) and incubated for $2 \mathrm{~h}$ ( $16 \mathrm{~h}$ for intergeneric matings) at $37{ }^{\circ} \mathrm{C}$ without shaking. Mixtures were resuspended in saline phosphate buffer (Cannon et al., I $974 a$ ) and plated on selective media; for intergeneric matings selective plates were incubated for 3 to 5 days and then transferred to room temperature for up to 7 days, because exconjugants sometimes showed long delays in colony formation.

Transfer of P-group plasmids occurred more efficiently when mating mixtures were incubated on an agar surface. A $0.1 \mathrm{ml}$ sample of late-exponential-phase culture of the donor was mixed with $0^{\circ} \mathrm{I} \mathrm{ml}$ of a late-exponential-phase recipient culture, spread on nutrient agar and incubated for $6 \mathrm{~h}$ at $37^{\circ} \mathrm{C}$. Bacteria were scraped off into saline phosphate buffer and plated on selective media. All matings employing P-group plasmids were performed in this fashion except where otherwise stated; for Erwinia herbicola a similar procedure, with $\mathrm{I} 6 \mathrm{~h}$ incubation, was used with an F-group plasmid.

Nitrogenase assays. Acetylene reduction was the usual measure of nitrogenase activity. Either Pankhurst tubes were used (Postgate, I 972) or 0. I ml of an overnight nutrient broth culture was added to $5 \mathrm{ml}$ NFDM, containing casein hydrolysate $(100 \mu \mathrm{g} / \mathrm{ml})$ and tryptophan $(25 \mu \mathrm{g} / \mathrm{ml})$ for Trp $^{-}$strains, in a sterile $7 \mathrm{ml}$ bijou bottle. Cultures were capped with Suba-seal closures (William Freeman Ltd, Barnsley, Yorkshire) equilibrated to atmospheric pressure with a sterile needle and incubated at $30{ }^{\circ} \mathrm{C}$. After 16 to $20 \mathrm{~h}$, when visible growth had occurred, I $\mathrm{ml}$ acetylene was injected.

When specific activities were required, cultures $(5 \mathrm{ml})$ were grown anaerobically in conical flasks $(25 \mathrm{ml}$ ) then flushed with argon and $2 \mathrm{ml}$ acetylene was injected. With $S$. typhimurium I $\mathrm{ml}$ samples were removed aseptically and anaerobically from a growing Pankhurst tube culture and injected into a Suba-sealed $\mathrm{I} 8 \mathrm{ml}$ Warburg flask containing argon $+0 . \mathrm{I} \mathrm{atm}$ $\mathrm{C}_{2} \mathrm{H}_{2}$. Alkaline pyrogallol supported on cotton wool was present in its side-arm. Tests of specific activity lasted for 0.5 to $3 \mathrm{~h}$ at $30^{\circ} \mathrm{C}$.

Ethylene production was measured by injecting $0.5 \mathrm{ml}$ gas samples into a Pye 104 gasliquid chromatograph fitted with a $45 \mathrm{~cm}$ Porapak $\mathrm{R}$ column (I $\mathrm{mm}$ internal diameter) at $37^{\circ} \mathrm{C}$, with $\mathrm{N}_{2}$ as carrier gas at a flow rate of $7 \mathrm{ml} / \mathrm{min}$. 
When it was necessary to screen many colonies for nitrogen fixation, clones were grown on NFDM agar at $30{ }^{\circ} \mathrm{C}$ under 0.99 atm $\mathrm{N}_{2}+0.0 \mathrm{I}$ atm $\mathrm{CO}_{2}$ in nylon bags (Hill, 1973). Nitrogen-fixing colonies of $K$. pneumoniae are brown on NFDM plates. $\mathrm{Nif}^{+} E$. coli colonies do not have such a distinctive colour, but are larger than Nif- colonies. With a derivative of $S$. typhimurium, ${ }^{15} \mathrm{~N}_{2}$ incorporation was assessed as described by Dixon \& Postgate (1972).

Gluconate 6-phosphate dehydrogenase. This was estimated by the colorimetric method of Peyru \& Fraenkel (1968).

Coll production. Colicin I production was determined by the method of Monk \& Clowes (I964). The indicator was E. coli KI2 WI 66 (ColV).

Segregation and acridine orange curing. These techniques were performed according to Willetts \& Bastarrachea (1972).

Partial purification of plasmid DNA. An overnight culture of host bacteria was diluted 2: 100 in 1.61 of minimal medium $\mathrm{C}$, grown to $2 \times 10^{8}$ to $4 \times 10^{8}$ cells $/ \mathrm{ml}$ and harvested by centrifugation at 0 to $2{ }^{\circ} \mathrm{C}$. The cells were resuspended in $56 \mathrm{ml}$ cold $25 \%$ sucrose in $50 \mathrm{~mm}$ tris- $\mathrm{HCl} \mathrm{pH} \mathrm{8.0} \mathrm{and} \mathrm{dispensed} \mathrm{as} 7 \mathrm{ml}$ portions in 8 centrifuge tubes kept on ice. A $\mathrm{I} \cdot 4 \mathrm{ml}$ portion of freshly-prepared cold lysozyme solution $(5 \mathrm{mg} / \mathrm{ml}$ in $0.25 \mathrm{M}$-tris- $\mathrm{HCl} \mathrm{pH} 8 \cdot 0$ ) was added to each tube followed in $5 \mathrm{~min}$ by $2.8 \mathrm{ml}$ cold $0.25 \mathrm{M}-\mathrm{Na}_{2} \mathrm{EDTA}(\mathrm{pH} 8 \cdot 0$ ) and in another $5 \mathrm{~min}$ by $\mathrm{I} 1 \cdot 2 \mathrm{ml} 2 \%(\mathrm{w} / \mathrm{v})$ sodium dodecyl sulphate (SDS) in $50 \mathrm{mM}-\mathrm{HCl} \mathrm{pH} 8 \cdot 0$ and $62.5 \mathrm{~mm}-\mathrm{Na}_{2}$ EDTA. Complete lysis coccurred immediately and $5.6 \mathrm{ml}$ of $5 \mathrm{M}-\mathrm{NaCl}$ was added to each tube. After overnight incubation on ice the crude cell lysates were centrifuged at $28000 \mathrm{~g}$ and $2{ }^{\circ} \mathrm{C}$ for $20 \mathrm{~min}$. The supernatant fluid was transferred to a $\mathrm{I} \cdot 51$ beaker on ice and the DNA precipitated by slowly adding $0.54 \mathrm{vol}$. cold isopropanol. The precipitate was collected by centrifugation at $1000 \mathrm{~g}$ and $2{ }^{\circ} \mathrm{C}$ for $\mathrm{I} 0 \mathrm{~min}$. The DNA was finally dissolved in approximately $3.0 \mathrm{ml}$ of TEN-C buffer (tris- $\mathrm{HCl}, \mathrm{pH} 8.0,20 \mathrm{~mm}$; $\mathrm{Na}_{2} \mathrm{EDTA}, \mathrm{I} \mathrm{mM}$; $\mathrm{NaCl}, 20 \mathrm{~mm} ; \mathrm{CaCl}_{2} \cdot 2 \mathrm{H}_{2} \mathrm{O}, 30 \mathrm{~mm}$ ) and insoluble material removed by centrifugation at $20000 \mathrm{~g}$ and $2{ }^{\circ} \mathrm{C}$ for $20 \mathrm{~min}$. DNA solutions were stored at $4{ }^{\circ} \mathrm{C}$ over a few drops of chloroform. Typical 230:260:280 ratios for DNA prepared by this procedure were $0.489: \mathrm{I}: 0.5 \mathrm{I}$, but examination by analytical $\mathrm{CsCl}$ centrifugation using the MSE Centriscan 75 showed that only I to $2 \%$ of material absorbing at $257 \mathrm{~nm}$ was DNA.

DNA-buoyant density determination. Solutions for centrifugation contained $\mathrm{I} \cdot \mathrm{O} \mathrm{ml} \mathrm{CsCl}$ (BDH; optical grade, density $\mathrm{I} \cdot 79 \mathrm{~g} / \mathrm{cm}^{3}$ ), approximately $3 \mu \mathrm{g}$ of FN68 DNA prepared as above, and $3 \mu \mathrm{g}$ of Clostridium perfringens DNA (Sigma; density $\mathrm{I} \cdot 69 \mathrm{I} \mathrm{g} / \mathrm{cm}^{3}$ ) as referent; the final density was adjusted with water to approximately $\mathrm{I} \cdot 7 \mathrm{I} \mathrm{g} / \mathrm{cm}^{3}$. These solutions were centrifuged in an MSE Centriscan 75 analytical ultracentrifuge at $44000 \mathrm{rev} . / \mathrm{min}$ and $25{ }^{\circ} \mathrm{C}$, and after $\mathrm{I} 6 \mathrm{~h}$ the extinction profiles at $254 \mathrm{~nm}$ of the resulting gradients were recorded. Buoyant densities were calculated as described by Schildkraut, Marmur \& Doty ( 1 962).

Transformation. The procedure of Cohen, Chang \& Hsu (1972) was used for transformation except that the low-phosphate medium $\mathrm{C}$ described above was used instead of their medium $\mathrm{Hr}$ for growing bacteria. $\mathrm{CaCl}_{2}$-treated cultures were exposed to FN68 DNA prepared as above, diluted tenfold in L-broth and incubated at $37^{\circ} \mathrm{C}$ for $90 \mathrm{~min}$ before plating.

Other procedures. Cannon et al. (1974 a) gave details for labelling, extraction, centrifugation and counting of DNA. The $\mathrm{S}$ values of peaks in sucrose gradients were calculated from the $\mathrm{S}$ values of ColEı CCC-DNA (23 $\mathrm{S}$ in neutral and $58 \mathrm{~S}$ in alkaline sucrose gradients) assuming a linear relationship between the $S$ value and the distance sedimented. Molecular weights were calculated from $S$ values in neutral sucrose gradients using the data of Bazaral \& Helinski (1968). 


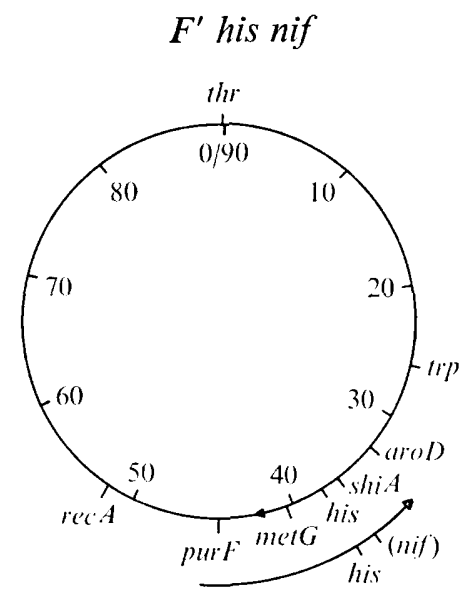

Fig. I. Simplified map of E. coli KI2 (Taylor \& Trotter, 1972), showing the point of origin and direction of chromosomal transfer by the donor strain, SBI824, and the lccation of metG (Blumenthal, 1972). Numbers inside the circle refer to chromosomal transfer time in minutes. The outer arrow indicates the origin and direction of transfer of chromosomal genes by the $K$. pneumoniae strain, HF3. The gene symbol for nitrogen fixation is nif (Streicher, Gurney \& Valentine, I971).

\section{RESULTS}

\section{Construction of a Nif $+H$ fr strain of E. coli $\mathrm{KI} 2$}

A nitrogen-fixing hybrid of an $\mathrm{Hfr}$ strain of $E$. coli was obtained by performing an intergeneric mating with a donor strain of $K$. pneumoniae. This donor, HF3 (RI44drd3) has been used previously to construct Nif ${ }^{+}$hybrids of E. coli C (Dixon \& Postgate, I972); it normally carries the R factor Ri44drd 3 and gives polarized transfer of chromosomal markers, with his and nif close to the transfer origin (Dixon, Cannon \& Postgate, 1975). The recipient used was SBI 824, a His- Hfr strain of E. coli with F integrated close to his (Fig. 1). Plasmid DNA in the supercoiled configuration was not observed in this strain (Fig. 2). His ${ }^{+}$exconjugants were selected and screened for inheritance of nif. Nine $\mathrm{His}^{+}$colonies were obtained and purified on the selection medium; only two were $\mathrm{Nif}^{+}$. Both $\mathrm{His}^{+} \mathrm{Nif}^{+}$isolates were sensitive to F-specific phages $\mathrm{MS}_{2}$ and $\mathrm{R}_{17}$, but neither was resistant to kanamycin, produced colicin I or was sensitive to I-specific phage, If 2 , and therefore neither hybrid carried RI44drd3. This conclusion was confirmed by the absence of CCC-DNA from the one of these strains examined, UNF43 (Fig. 2). This result was in striking contrast to the $\mathrm{Nif}^{+}$ hybrids of E. coli $\mathrm{C}$ derived from what was apparently the same Klebsiella donor, which harbour this R factor (Cannon et al., 1974a,b).

One of the Nif + isolates, designated UNF43, was used for further studies. In interrupted mating experiments between this strain and $\mathrm{J} 62-\mathrm{I}$, a $\operatorname{Trp}^{-} \mathrm{His}^{-}$recipient, the time of entry of his and $\operatorname{trp}$ were 5 and $20 \mathrm{~min}$ respectively. Twenty $\mathrm{His}^{+}$exconjugants obtained after Io min of mating were also $\mathrm{Nif}^{+}$, indicating that nif was also transferred as an early marker. Similar curves for his and trp transfer were obtained for the donor AB3II, the strain from which SBI 824 was derived, although the number of recombinants produced was ten-fold higher. The low number of recombinants obtained with UNF43 probably reflects the presence of heterologous Klebsiella DNA in the donor, which could reduce pairing between the donor and recipient chromosomes (Curtiss et al., 1968). 


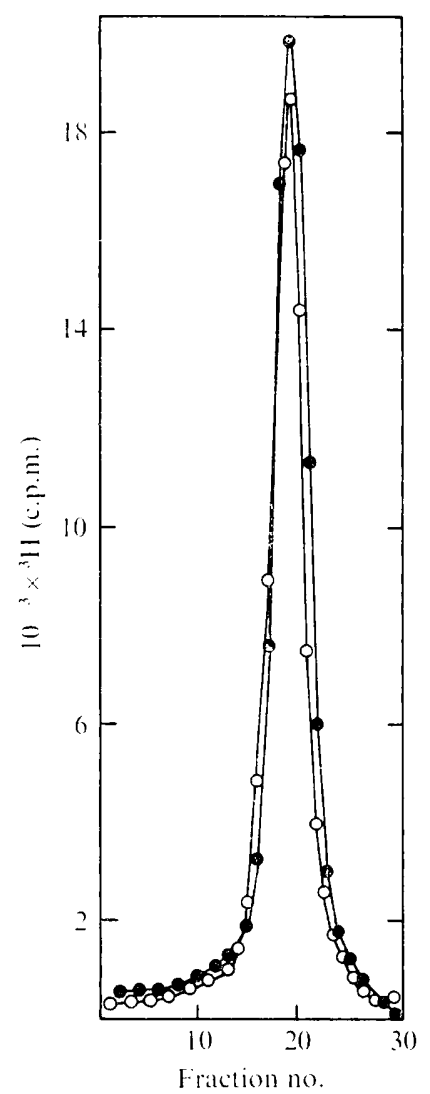

Fig. 2

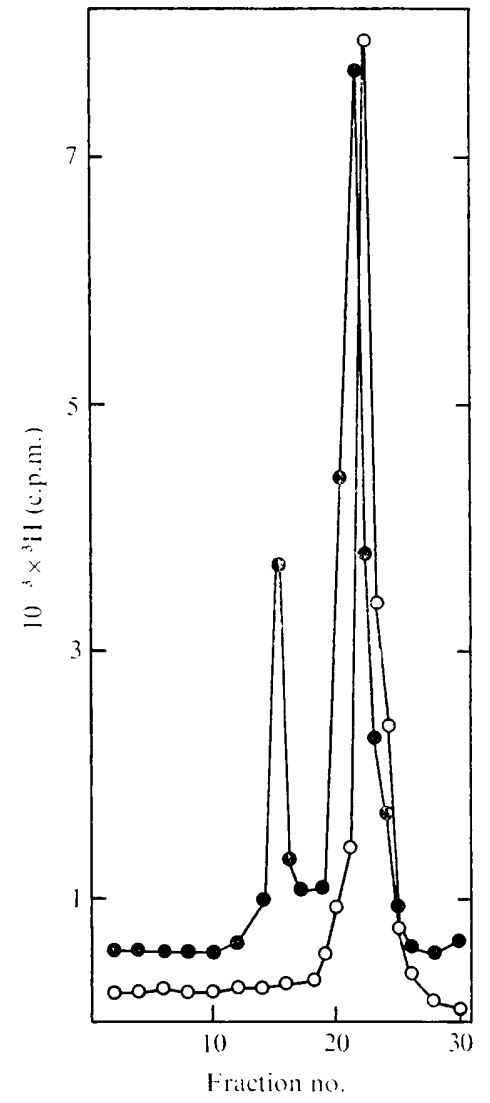

Fig. 3

Fig. 2. Profiles of labelled DNA in cleared lysates of E. coli SBI824 (๑), and UNF43 (O), after dyebuoyant density centrifugation at $\mathrm{I} 26000 \mathrm{~g}$ and $\mathrm{I} 5{ }^{\circ} \mathrm{C}$ for $\mathrm{I} 6 \mathrm{~h}$. Cleared lysates of $10 \mathrm{ml}$ cultures were prepared by a lysozyme-EDTA-Triton X-I 00 procedure (Cannon et al., I $974 a$ ). After centrifugation, fractions (10 drops) were collected on filter discs and assayed for ${ }^{3} \mathrm{H}$-radioactivity.

Fig. 3. Profiles of labelled DNA in cleared lysates of E. coli JC5466 (O), and JC5466(FN39) (•), after dye-buoyant density centrifugation at $126000 \mathrm{~g}$ and $15{ }^{\circ} \mathrm{C}$ for $16 \mathrm{~h}$. Cleared lysates of $30 \mathrm{ml}$ cultures were prepared by a lysozyme-EDTA.-Triton X-100 procedure (Cannon et al. 1974a). After centrifugation, fractions ( $\mathrm{I} O \mathrm{drops}$ ) were collected in styrene 'Microtiter' plates. A portion (O.OI ml) of each fraction was spotted on a filter disc and assayed for ${ }^{3} \mathrm{H}$-radioactivity.

\section{Isolation of an $F^{\prime}$ nif}

Exponential-phase cultures of the donor strain UNF43 and a $\mathrm{His}^{-}$recA nalA recipient JC5466 were mixed at a donor-recipient ratio of $1: 5$ and incubated for $60 \mathrm{~min}$. The mating was stopped by adding $25 \mu \mathrm{g}$ nalidixic acid/ml mating mixture. His ${ }^{+}$exconjugants were selected on a minimal medium containing tryptophan, spectinomycin and nalidixic acid. Forty $\mathrm{His}^{+}$isolates were purified on the selection medium; 12 were $\mathrm{Nif}^{+}$and sensitive to F-specific phage MS2. One $\mathrm{Nif}^{+}$isolate, carrying a presumptive $\mathrm{F}^{\prime}$ nif factor designated FN39, was studied in detail. In a qualitative test on a u.v.-irradiated spread plate, this strain was as sensitive to u.v. irradiation as its parent $\mathrm{JC} 5466$ and was therefore presumably rec $A$. It transferred his at high frequency to $\mathrm{AB} 2.463$, a rec $A$ strain, and to SBI8OI, a his deletion strain of KI2 (Table 2, Expts I and 2). Twenty exconjugants purified from each cross were $\mathrm{Nif}^{+}, \mathrm{MS} 2$-sensitive and re-transferred nif and his when replica-plated on to a lawn 
Table 2. Transfer properties of nif plasmids

\begin{tabular}{|c|c|c|c|c|c|}
\hline Expt. & Donor & Recipient & Selection & $\begin{array}{l}\text { Transfer } \\
\text { frequency }\end{array}$ & Exconjugant phenotype \\
\hline I & JC5466(FN39) & $\mathrm{AB} 2463$ & $\mathrm{His}^{+}$ & $2 \times 10^{-1}$ & 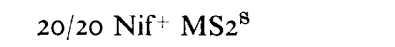 \\
\hline 2 & JC5466(FN39) & SBI 8OI & $\mathrm{His}^{+}$ & $3 \times 10^{-1}$ & $10 / 10 \mathrm{Nif}^{+} \mathrm{MS}_{2}{ }^{\mathrm{S}}$ \\
\hline 3 & SBI $80 \mathrm{I}(\mathrm{FN} 39)(\mathrm{R} 68)$ & UNF5O2 & $\begin{array}{l}\mathrm{His}^{+} \\
\mathrm{Km} \\
\text { Carb } \\
\text { Carb His }\end{array}$ & $\begin{array}{l}7 \times 10^{-1} \\
1 \times 10^{-4} \\
7 \times 10^{-2} \\
3 \times 10^{-4}\end{array}$ & 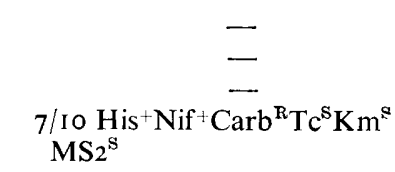 \\
\hline 4 & JC5466(FN68) & $\mathrm{AB} 2463$ & $\begin{array}{l}\mathrm{His}^{+} \\
\text {Carb } \\
\text { Carb His }\end{array}$ & $\begin{array}{l}3 \times 10^{-1} \\
3 \times 10^{-1} \\
3 \times 10^{-1}\end{array}$ & $\begin{array}{l}\text { I 35/135 } \mathrm{Carb}^{\mathrm{R}} \mathrm{Nif}^{+} \\
\text {I03/IO3 } \mathrm{His}^{+} \mathrm{Nif}- \\
-\end{array}$ \\
\hline 5 & $\mathrm{JC5} 566(\mathrm{FN} 68)$ & SBI 80 I & $\begin{array}{l}\text { Carb } \\
\mathrm{His}^{+}\end{array}$ & $\begin{array}{l}3 \times 10^{-1} \\
2 \times 10^{-1}\end{array}$ & $\begin{array}{l}\text { 10/10 } \mathrm{His}^{+} \mathrm{Nif}^{+} \\
\text {10/10 } \mathrm{Nif}^{+} \mathrm{Carb}^{\mathrm{R}}\end{array}$ \\
\hline
\end{tabular}

of JC5466 spread on selection medium. The presence of a plasmid in JC5466 (FN39) was confirmed by comparing the buoyant density profiles of DNA from this strain and its parent strain JC5466 in CsCl-ethidium bromide gradients (Fig. 3).

\section{Interaction between $\mathrm{FN}_{39}$ and the $R$ factor, $\mathrm{R} 68$}

Translocation of carbenicillin resistance from plasmids of the $\mathrm{P}$ compatibility group to other plasmids has been demonstrated (Beringer, I974; Hedges \& Jacob, I 974). We followed a similar procedure to introduce carbenicillin resistance into the $\mathrm{F}^{\prime}$ nif, FN39. The R factor, R68, a member of the $\mathrm{P}$ compatibility group (Holloway \& Richmond, I973) conferring resistance to ampicillin-carbenicillin, kanamycin and tetracycline, was introduced into SBI80I carrying FN39. A broth mating was carried out between SBI80I (FN39) (R68) and a His-Rec ${ }^{+}$recipient, UNF502 (Table 2, Expt 3). Under these conditions, transfer of the F-prime (selection for $\mathrm{His}^{+}$) occurred at a much higher frequency than kanamycin resistance, a marker on R68. Transfer of carbenicillin (Carb), however, occurred at an intermediate frequency. Selection for co-transfer of both Carb and his should therefore give a considerable enrichment for F-primes to which carbenicillin resistance has been translocated. Indeed, 7 out of 10 exconjugants selected for inheritance of both markers appeared to contain a recombinant plasmid; they were sensitive to kanamycin and tetracycline, were $\mathrm{His}^{+} \mathrm{Nif}^{+}$ and were lysed by MS2 phage. The remaining three exconjugants apparently retained both plasmids, they were resistant to kanamycin and tetracycline and transferred his and Carb independently. However, strains carrying the recombinant plasmid, designated FN68, gave co-transfer of his nif and carbenicillin resistance (Table 3, Expts 4 and 5).

\section{Compatibility properties of $F^{\prime}$ nif plasmids}

Plasmids of the P compatibility group show mutual exclusion and cannot co-exist in the same host. Hence, a reduction in transfer frequency, indicative of surface exclusion, was observed when a strain carrying $\mathrm{R} 75 \mathrm{I}$ was mated with a recipient carrying R68 (Table 3, Expts I and 2). FN68 did not exclude entry of R75I and both plasmids co-existed stably (Table 3 Expt 3) indicating that FN68 does not retain P compatability. Strains carrying FN68 and $\mathrm{FN} 39$ did exclude an $\mathrm{F}^{\prime}$ factor $\mathrm{F}^{\prime} \mathrm{Cm}$, indicating that both plasmids are members of the F compatibility group (Table 3, Expts 4,5 and 6). However, occasional super-infection of the resident plasmid occurred since, in the majority of exconjugants, markers on both 
Table 3. Compatibility properties of $F^{\prime}$ nif plasmids

\begin{tabular}{|c|c|c|c|c|c|}
\hline $\begin{array}{c}\text { Expt. } \\
\text { no. }\end{array}$ & Donor & Recipient & Selection & $\begin{array}{l}\text { Transfer } \\
\text { frequency* }\end{array}$ & Exconjugant phenotype \\
\hline I & $\mathrm{J} 62-2\left(\mathrm{R}_{75} \mathrm{I}\right)$ & SBI $80 \mathrm{I}$ & Trim & $>\mathrm{I}$ & - \\
\hline 2 & $\mathrm{~J} 62-2\left(R_{75} \mathrm{I}\right)$ & $\mathrm{SB1} 80 \mathrm{I}(\mathrm{R} 68)$ & Trim & $2 \times 10^{-4}$ & 一 \\
\hline 3 & $\mathrm{~J} 62-2(\mathrm{R} 75 \mathrm{I})$ & SBI 80I (FN68) & Trim & $6 \times 10^{-1}$ & 20/20 $\operatorname{Trim}^{\mathrm{R}} \mathrm{Carb}^{\mathrm{R}} \mathrm{His} \mathrm{Nif}^{+}$ \\
\hline 4 & $\begin{array}{l}\text { Prototrophic KI } 2 \\
\left(\mathrm{~F}^{\prime} \mathrm{Cm}\right)\end{array}$ & $\mathrm{SBI} 80 \mathrm{I}$ & $\mathrm{Cm}$ & $7 \times 10^{-1}$ & - \\
\hline 5 & $\begin{array}{l}\text { Prototrophic K12 } \\
\left(\mathrm{F}^{\prime} \mathrm{Cm}\right)\end{array}$ & SNI $801\left(F_{39}\right)$ & $\mathrm{Cm}$ & $2 \times 10^{-4}$ & $\begin{array}{l}28 / 30 \mathrm{Cm}^{\mathrm{R}} \mathrm{His}^{+} \mathrm{Nif}^{+} \\
2 / 30 \mathrm{Cm}^{\mathrm{R}} \mathrm{His}^{-} \mathrm{Nif}^{-}\end{array}$ \\
\hline 6 & $\begin{array}{l}\text { Prototrophic KI } 2 \\
\left(\mathrm{~F}^{\prime} \mathrm{Cm}\right)\end{array}$ & SB180I(FN68) & $\mathrm{Cm}$ & $4 \times 10^{-5}$ & 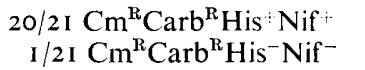 \\
\hline
\end{tabular}

* Matings with R75I were performed by the surface mating procedure described in Methods.

plasmids co-existed stably (Table 3, Expts 5 and 6). In some clones, this was probably the result of $\mathrm{F}^{\prime}$ fusion; since one out of 30 carrying both $\mathrm{FN} 39$ and $\mathrm{F}^{\prime} \mathrm{Cm}$ and six out of $2 \mathrm{I}$ clones carrying FN68 and 'F' $\mathrm{Cm}$ co-transferred his and $\mathrm{Cm}^{\mathrm{R}}$ to $\mathrm{JC} 5466$ at high frequency.

\section{Stability of $F^{\prime}$ nif plasmids}

In the $\operatorname{rec} A$ strain, JC5466, the F-prime $\mathrm{FN} 39$ gave rise to spontaneous His- Nif- segregants at a frequency of $10 \%$ and was cured at a $100 \%$ efficiency by acridine orange. In one cured clone examined no CCC-DNA was detected in $\mathrm{CsCl}$-ethidium bromide gradients. FN68 did not give spontaneous segregants at high frequency; although his and nif were cured $100 \%$ efficiently by acridine orange treatment, carbenicillin resistance was extremely stable. Presumably Carb became stabilized by integration into the host chromosome (Hedges \& Jacob, 1974).

\section{Other markers carried by $F^{\prime}$ nif plasmids}

Derivatives of JC5466 carrying FN39 or FN68 were tested for their ability to donate other determinants located close to the his operon; transfer of purF, metG, shiA and aroD was tested (see Fig. I). Presumably, neither FN39 nor FN68 carried purF, since transfer of this determinant was not detected either by direct selection or as an unselected marker in Carb ${ }^{\mathrm{k}}$ exconjugants (Table 4, Expts I and 2). Both $\mathrm{F}^{\prime}$ factors carried met $G$, since his met cotransfer was detected in crosses with C1463, a met $G$ derivative of $E$. coli (Table 4, Expts 3 and 4). Thirty $\mathrm{His}^{+}$exconjugants derived from a mating with FN68 inherited met $G$, and $\mathrm{Met}^{+}$exconjugants inherited his (Table 4, Expt 4). When FN68 or FN39 was transferred to $\mathrm{AB} 2880$, a His ${ }^{-}$shiA aro $D$ recipient, His ${ }^{+}$exconjugants from each mating inherited shiA, a marker located close to his, but not aroD, and no co-transfer of shiA and aroD could be detected (Table 4, Expts 5 and 6).

Both plasmids most probably carry a determinant for gluconate 6-phosphate dehydrogenase (gnd). Derivatives of strain SB I 80I, a gnd deletion background, carrying each plasmid gave a positive reaction for gluconate 6-phosphate dehydrogenase when tested by the rapid colorimetric assay for this enzyme (Peyru \& Fraenkel, I968), whereas SBI80I itself was clearly negative in this assay. The nitrogenase activity of plasmid-containing strains in vivo as measured by acetylene reduction and assimilation of ${ }^{15} \mathrm{~N}_{2}$ is shown in Table 5. The specific activity for acetylene reduction of $E$. coli strains carrying nif plasmids was equivalent to that shown by the natural nitrogen-fixer, $K$. pneumoniae.

From the above results we conclude that both plasmids carry nif genes and probably a 
Table 4. Other markers carried on F'nif plasmids

\begin{tabular}{|c|c|c|c|c|c|}
\hline $\begin{array}{c}\text { Expt. } \\
\text { no. }\end{array}$ & Donor & Recipient & Selection & $\begin{array}{l}\text { Transfer } \\
\text { frequency }\end{array}$ & $\begin{array}{l}\text { Exconjugant } \\
\text { phenotype }\end{array}$ \\
\hline I & $\mathrm{JC} 5466\left(\mathrm{FN}_{39}\right)$ & AB $396^{*}$ & PurF ${ }^{+}$ & $<\mathrm{I} \times \mathrm{IO}^{-7}$ & - \\
\hline 2 & JC5466(FN68) & AB $396^{*}$ & $\begin{array}{l}\text { PurF }{ }^{+} \\
\text {Carb }\end{array}$ & $\begin{array}{r}<1 \times 10^{-7} \\
5 \times 10^{-1}\end{array}$ & $\mathrm{o} / 30 \overline{\mathrm{PurF}^{+}}$ \\
\hline 3 & JC5466(FN39) & $\mathrm{CI} 463$ & $\begin{array}{l}\mathrm{His}^{+} \\
\mathrm{His}^{+} \mathrm{MetG}^{+}\end{array}$ & $\begin{array}{l}1 \times 10^{-1} \\
1 \times 10^{-1}\end{array}$ & - \\
\hline 4 & JC5466(FN68) & $\mathrm{C} 1463$ & $\begin{array}{l}\mathrm{His}^{+} \\
\text {MetG }^{+}\end{array}$ & $\begin{array}{l}2 \times 10^{-1} \\
2 \times 10^{-1}\end{array}$ & $\begin{array}{l}\text { 30/30 MetG } \\
30 / 30 \mathrm{His}^{+}\end{array}$ \\
\hline 5 & JC5466(FN39) & AB2880* & $\begin{array}{l}\mathrm{His}^{+} \\
\text {ShiA }^{+} \\
\text {AroD }^{+} \text {ShiA }\end{array}$ & $\begin{array}{l}3 \times 10^{-1} \\
3 \times 10^{-1} \\
5 \times 10^{-7}\end{array}$ & o/10 AroD \\
\hline 6 & JC5466(FN68) & $\mathrm{AB} 2880^{*}$ & $\begin{array}{l}\mathrm{His}^{+} \\
\text {ShiA }^{+} \\
\text {AroD }^{+} \text {ShiA }^{+}\end{array}$ & $\begin{array}{l}5 \times 10^{-1} \\
4 \times 10^{-4} \\
1 \times 10^{-7}\end{array}$ & o/10 AroD \\
\hline
\end{tabular}

Table 5. Nitrogenase activity in strains carrying $F^{\prime}$ nif plasmids

\begin{tabular}{|c|c|c|}
\hline Strain & $\begin{array}{l}\text { Ethylene produced } \\
(\mathrm{nmol} / \mathrm{mg} \text { protein } / \mathrm{min})\end{array}$ & Atom $\%{ }^{15} \mathrm{~N}$ excess $*$ \\
\hline \multicolumn{3}{|c|}{ Escherichia coli $\mathrm{K} \mathbf{2}$} \\
\hline JC5466 & $<0 . I$ & NT \\
\hline JC5466(FN68) & 40 & I 20 \\
\hline JC5466(FN39) & 57 & NT \\
\hline \multicolumn{3}{|c|}{ Salmonella typhimurium } \\
\hline LT7-120I & $<0.01$ & 0.02 \\
\hline UNF602 & $2-20$ & 0.61 \\
\hline \multicolumn{3}{|c|}{ Klebsiella pneumoniae } \\
\hline HF3 & 63 & $\mathrm{I} \cdot 88$ \\
\hline
\end{tabular}

chromosomal region corresponding to the met $G$ gnd his shiA region of the $E$. coli chromosome, but not including the purF and aro $D$ genes.

\section{Intergeneric transfer of nif plasmids}

Tubb (1974) used FN68 to transfer nif genes to gln mutants of Klebsiella aerogenes, providing evidence for the involvement of glutamine synthetase in the ammonia regulation of nitrogenase. Transfer of FN68 from $E$. coli to a His- Nif $-K$. pneumoniae occurred at low frequency and resulted in segregation of carbenicillin resistance from his and nif. Using the solid surface mating procedure, only one out of $150 \mathrm{His}^{+}$exconjugants was carbenicillinresistant whereas 87 out of $96 \mathrm{Carb}^{\mathrm{R}}$ exconjugants inherited both his and ability to fix nitrogen (Table 6, Expt I). Five of the $\mathrm{His}^{+} \mathrm{Carb}^{\mathrm{R}}$ exconjugants tested were not sensitive to MS2 phage and re-transfer of these determinants to $E$. coli could not be detected. This is characteristic of the behaviour of F-like plasmids in K. pneumoniae M5al (Dixon \& Postgate, I97I).

FN68 could be transferred to $S$. typhimurium at low frequency but without expression of $\mathrm{F}$ as sensitivity to the F-specific MS2 phage (Table 6, Expt 2). Segregation again occurred, but in this case transfer of $\mathrm{Carb}^{\mathrm{R}}$ preponderated about 20-fold over his nif transfer. Although 
Table 6. Intergeneric matings with FN68

\begin{tabular}{|c|c|c|c|c|c|c|}
\hline $\begin{array}{l}\text { Expt. } \\
\text { no.* }\end{array}$ & Donor & Recipient & Selection & $\begin{array}{l}\text { Transfer } \\
\text { frequency }\end{array}$ & Exco & onjugant phenotype \\
\hline \multirow[t]{2}{*}{ I } & \multirow{2}{*}{$\begin{array}{l}\text { Escherichia coli } \\
\text { K12 } \\
\text { JC5466(FN68) }\end{array}$} & \multirow[t]{2}{*}{$\begin{array}{l}\text { Klebsiella pneumoniae } \\
\text { UNFI } 24\end{array}$} & $\mathrm{His}^{+}$ & $5 \times 10^{-4}$ & $\begin{array}{r}149 / 150 \\
1 / 150\end{array}$ & $\begin{array}{l}\mathrm{His}^{+} \mathrm{Nif}^{+} \mathrm{Carb}^{\mathrm{s}} \\
\mathrm{His}^{+} \mathrm{Nif}^{+} \mathrm{Carb}^{\mathrm{R}}\end{array}$ \\
\hline & & & $\operatorname{Carb}^{\mathrm{R}}$ & $\mathrm{I} \times \mathrm{IO}^{-5}$ & $\begin{array}{r}87 / 96 \\
9 / 96\end{array}$ & $\begin{array}{l}\mathrm{His}^{+} \mathrm{Nif}^{+} \mathrm{Carb}^{\mathrm{R}} \\
\mathrm{His}^{-} \mathrm{Nif}^{-} \mathrm{Carb}^{\mathrm{R}}\end{array}$ \\
\hline 2 & JC5466(FN68) & $\begin{array}{l}\text { Salmonella typhimurium } \\
\text { LT7-I } 201\end{array}$ & $\begin{array}{l}\mathrm{His}^{+} \\
\mathrm{Carb}^{\mathrm{R}}\end{array}$ & $\begin{array}{l}1 \times 10^{-7} \\
2 \times 10^{-6}\end{array}$ & $\begin{array}{l}5 / 5 \\
5 / 5\end{array}$ & $\begin{array}{r}\mathrm{Nif}^{\dagger} \mathrm{Carb}^{\mathrm{R}} \mathbf{M S}_{2}{ }^{\mathrm{R}} \\
\mathrm{His}^{-} \mathrm{Nif}^{-} \mathrm{Carb}^{\mathrm{R}} \mathrm{MS}_{2}{ }^{\mathrm{R}}\end{array}$ \\
\hline 3 & JC5466(FN68) & $\begin{array}{l}\text { Erwinia herbicola } \\
\text { YC74 }\end{array}$ & $\stackrel{\mathrm{Carb}}{\mathrm{R}}^{-}$ & $1 \times 10^{-7}$ & $\begin{array}{l}5 / 12 \\
7 / 12\end{array}$ & $\begin{array}{l}\mathrm{Nif}^{-} \mathrm{Carb}^{\mathrm{R}} \mathrm{MS}_{2}{ }^{\mathrm{S}} \\
\mathrm{Nif}^{-} \mathrm{Carb}^{\mathrm{R}} \mathbf{M S}_{2}{ }^{\mathrm{R}}\end{array}$ \\
\hline
\end{tabular}

* Matings I and 3 were performed using the agar surface mating procedure; mating 2 was performed in broth.

His ${ }^{+}$exconjugants grew readily in complex medium at $37{ }^{\circ} \mathrm{C}$, growth on minimal medium occurred at $30^{\circ} \mathrm{C}$ but not at $37^{\circ} \mathrm{C}$, suggesting that expression of the FN68 his genes was temperature-sensitive in this host. Nitrogenase activity was also only detectable at $30^{\circ} \mathrm{C}$, but synthesis of this enzyme is naturally temperature-sensitive in this strain of $K$. pneumoniae (see Postgate, 1974). One Nif ${ }^{+}$exconjugant, UNF602, was checked for fixation with ${ }^{15} \mathrm{~N}_{2}$ (Table 5) and its identity as S. typhimurium was reconfirmed using the API system for identification of Enterobacteriaceae (Hughes \& Hughes Ltd, Brentwood, Essex). The low levels of acetylene-reducing activity (Table 5) probably signify low levels of nif expression, because the normal activity of the parent strain varies over only a twofold range according to age and test conditions. It was not due to extra oxygen sensitivity, because the technique of anaerobic handling of samples recorded in Methods was used. Acetylene reduction by this strain was repressed in cultures with $\mathrm{I} \mathrm{mg}\left(\mathrm{NH}_{4}\right)_{2} \mathrm{SO}_{4} / \mathrm{ml}$ medium.

Transfer of carbenicillin resistance at low frequency occurred in surface, but not broth, matings with Er. herbicola. Five out of $12 \mathrm{Carb}^{\mathrm{IR}}$ exconjugants tested were $\mathrm{MS} 2$ sensitive; none of I $_{2} \mathrm{Carb}^{\mathrm{k}}$ exconjugants tested expressed nitrogen-fixing ability (Table 6, Expt 3). One $\mathrm{F}^{+} \mathrm{Carb}^{\mathrm{R}}$ derivative was mated with $E$. coli $\mathrm{C} 603$ overnight in broth at $37^{\circ} \mathrm{C}$; $\mathrm{Carb}^{\mathrm{R}}$ progeny were obtained at about $10^{-4} /$ donor cell but none of 15 clones tested was $\mathrm{His}^{+}$or $\mathrm{Nif}^{+}$.

Neither his nor carbenicillin resistance transfer was detected in surface or liquid matings with the $\mathrm{His}^{-}$strain of $P$. mirabilis.

\section{Buoyant density of FN68 DNA}

Partially-purified FN68 DNA from E. coli JC5466 separated into two species of buoyant densities $\mathrm{I} \cdot 7 \mathrm{IO}$ and $\mathrm{I} \cdot 7 \mathrm{I} 4 \mathrm{~g} / \mathrm{cm}^{3}$ on analytical $\mathrm{CsCl}$ gradients (Fig. 4). The peak at buoyant density $\mathrm{I} \cdot 7 \mathrm{I} 0 \mathrm{~g} / \mathrm{cm}^{3}$ which is identical to that of E. coli DNA is most likely JC5466 chromosomal DNA, and since FN68 was constructed of $E$. coli and Klebsiella DNA, the shoulder at the intermediate buoyant density of $1 \cdot 714 \mathrm{~g} / \mathrm{cm}^{3}$ is probably FN68 DNA. This shoulder represents $1 \mathrm{I} \cdot 5 \%$ of the total peak area.

\section{Sedimentation analysis of $F^{\prime}$ nif factors}

Closed circular DNA obtained by $\mathrm{CsCl}$-ethidium bromide centrifugation from E. coli JC5466 carrying FN39 or FN68 was analysed by „velocity centrifugation in neutral and alkaline sucrose gradients. Four molecular species of $S$ values 140, 103, 86 and 64 in neutral 


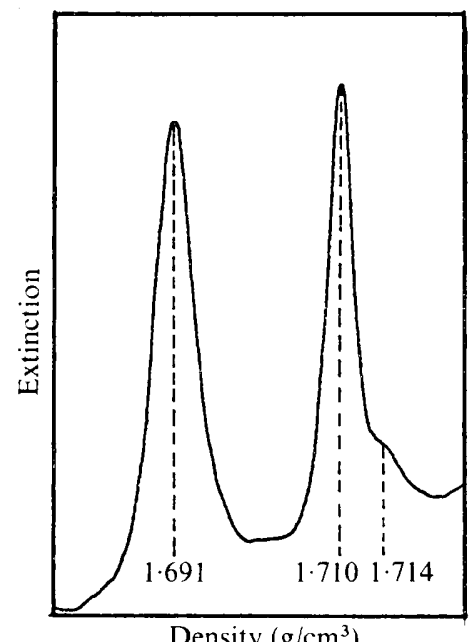

Density $\left(\mathrm{g} / \mathrm{cm}^{3}\right)$

Fig. 4

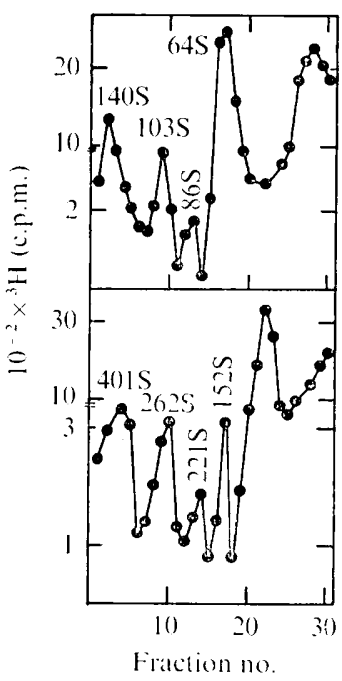

Fig. 5

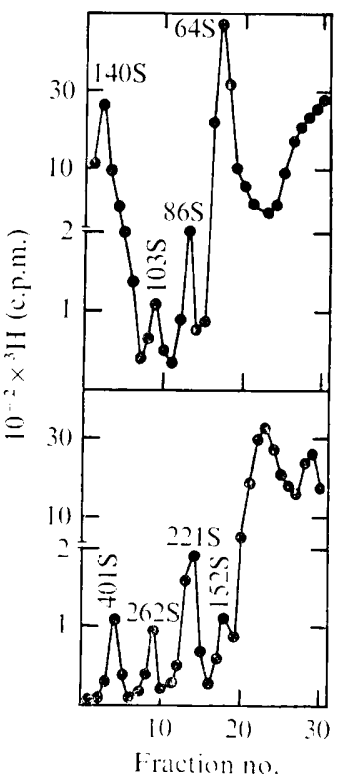

Fig. 6

Fig. 4. Buoyant density profile of DNA from a cleared lysate of JC5466(FN68) after analytical CsCl centrifugation in an MSE Centriscan 75 at $44000 \mathrm{rev} . / \mathrm{min}$ and $25^{\circ} \mathrm{C}$ for $16 \mathrm{~h}$. Cleared lysate DNA was purified as described in the text. The peak at density $\mathrm{I} \cdot 69 \mathrm{I} \mathrm{g} / \mathrm{cm}^{3}$ is of Clostridium perfingens DNA.

Fig. 5. Profiles of ${ }^{3} \mathrm{H}$-labelled DNA from $E$. coli $\mathrm{JC} 5466\left(\mathrm{FN}_{39}\right)$, analysed by velccity centrifugation in neutral (top) and alkaline (bottom) 5 to $20 \%$ sucrose gradients ( $5 \mathrm{ml}$ ). Supercoiled DNA, obtained from dye-buoyant density gradients, was dialysed against TES buffer ( $10 \mathrm{~mm}$-tris- $\mathrm{HCl}, \mathrm{I} \mathrm{mm}$ $\mathrm{Na}_{2}$ EDTA, $\left.100 \mathrm{~mm}-\mathrm{NaCl}, \mathrm{pH} 8 \cdot 0\right)$. Portions $(150 \mu \mathrm{l})$ of the pooled fractions, mixed with $50 / \mathrm{ll}$ of ${ }^{14} \mathrm{C}$-labelled ColE I CCC-DNA, were layered on gradients and centrifuged for $36.5 \mathrm{~min}$ (top) and $20 \mathrm{~min}(\mathrm{bcttom})$ at $\mathrm{I} 20000 \mathrm{~g}$ in a 52 rotor at $20^{\circ} \mathrm{C}$ using a Christ $\omega$ II ultracentrifuge. Gradients were fractionated by drop collection ( 7 drops/fraction) directly on to filter discs and trichloroacetic acid precipitate label assayed for ${ }^{3} \mathrm{H}$-radioactivity.

Fig. 6. Profiles of ${ }^{3} \mathrm{H}$-labelled DNA from $E$. coli JC5466(FN68), analysed by velocity centrifugation in neutral (top) and alkaline (bottom) 5 to $20 \%$ sucrose gradients $(5 \mathrm{ml})$. For details see Fig. 5 .

sucrose gradients of either FN39 or FN68 (Figs. 5, 6, top) were CCC-DNA because twoto threefold increases occurred in these respective $S$ values in alkaline sucrose (Figs. 5, 6, bottom). The DNA profiles were reproducible on 18 gradients of each type. Molecular weights of $279 \pm 9,136 \pm 3,90 \pm \mathrm{I}$ and $44 \pm \mathrm{I}$ megadaltons correspond to these $\mathrm{S}$ values. The largest molecules were thus twice the size of the next largest, the molecular weight of which (I36 megadaltons) was approximately the sum of those of the two smaller plasmids. Although carbenicillin resistance genes were carried on FN68 but not on FN39, the molecular weights of both F-primes were indistinguishable by velocity centrifugation in sucrose gradients. A comparable analysis of closed circular DNA from E. coli SBI80 I carrying FN68 revealed four comparable CCC species.

\section{Transformation of E. coli and Klebsiella with F'nif DNA}

Transformations of E. coli $\mathrm{C} 603$ and $K$. pneumoniae with plasmid-enriched DNA from two different hosts carrying FN68 are shown in Table 7. All His ${ }^{+}$transformants of $\mathrm{C}^{6} 3$ using FN68 DNA from JC5466 were Nif- Carb\$ but produced F-type sex-pili, indicating 


\section{Table 7. Transformation of E. coli and K. pneumoniae by FN68 DNA}

\begin{tabular}{|c|c|c|c|c|}
\hline Origin of FN68 DNA & Recipient & Selection & $\begin{array}{c}\text { Transformants } \\
\text { / } / \mathrm{g} \text { DNA }\end{array}$ & $\begin{array}{l}\text { Phenotype of } \\
\text { transformants }\end{array}$ \\
\hline JC5466(FN68) & $\mathrm{c} 603$ & $\mathrm{His}^{+}$ & $9 \cdot 3 \times 10^{2}$ & 10/10 $\mathrm{MS}_{2}^{\mathrm{s}} \mathrm{Nif}^{-} \mathrm{Carb}^{\mathrm{s}}$ \\
\hline JC5466(FN68) & $\mathrm{c} 603$ & $\mathrm{Carb}^{R}$ & 0 & - \\
\hline SBI 8OI (FN68) & UNF925 & $\mathrm{His}^{+}$ & $2.5 \times 10^{3}$ & $8 / 8 \mathrm{Nif}^{-\mathrm{Carb}^{\mathbf{R}}}$ \\
\hline SBI 80 I(FN68) & UNF925 & $\mathrm{Carb}^{\mathrm{R}}$ & $3.0 \times 10^{3}$ & $8 / 56 \mathrm{His}^{+} \mathrm{Nif}$ \\
\hline
\end{tabular}

co-transformation of sex factor activity. No $\mathrm{Carb}^{\mathrm{R}}$ transformants were obtained by direct selection in three repetitions of this experiment. In contrast, when FN68 DNA from SBI8OI was used and the recipient was UNF925, all His ${ }^{+}$transformants were $\mathrm{Nif}^{+} \mathrm{Carb}^{\mathrm{R}}$ while eight out of the $56 \mathrm{Carb}^{\mathrm{R}}$ transformants were $\mathrm{His}^{+} \mathrm{Nif}^{+}$. The results can be interpreted best if the dissociation of FN68 into component replicons, suggested by the sucrose gradient analysis, led to plasmids which functioned more readily in transformation than the parent F-primes, because of their smaller size. Although the frequency with FN68-enriched DNA was lower than that reported by Cohen et al. (1972) for highly purified small plasmids in $E$. coli, the numbers of $\mathrm{Carb}^{\mathrm{R}}$ transformants increased with DNA concentration, reaching a maximum at $0.75 \mu \mathrm{g} / \mathrm{ml}$.

\section{DISCUSSION}

We have constructed an F-prime nif factor by a procedure routinely used for the isolation of $F^{\prime}$ factors (Low, 1968). A drug-resistant derivative of the $F^{\prime}$ was constructed by translocation of carbenicillin resistance genes from a $\mathrm{P}$ plasmid. Similar genetic techniques to those described here could be employed to construct F-prime factors carrying other regions of the K. pneumoniae chromosome.

The DNA of the F-prime factors was derived from diverse origins; it included F-factor DNA, probably both E. coli and Klebsiella chromosomal genes and, in the case of FN68, P plasmid DNA. The molecular stability of the F-primes could be affected by their heterologous composition; hence the complex molecular pattern observed. The molecular state of some plasmids varies with their hosts (Clowes, I972). RI, for example, has been isolated from $E$. coli as a circular molecule of molecular weight 68 megadaltons while in Proteus it dissociates into component replicons of molecular weight 58 and 10 megadaltons. Recently, Oliver, Morris \& Whitfield ( 1974 ) have shown that an $\mathrm{F}^{\prime}$ his gnd and a cryptic plasmid were present in $S$. typhimurium as a composite molecule with a molecular weight equal to the sum of its precursors' molecular weights. However, in an E. coli host three CCC-species were detected with molecular weights corresponding to those of the composite and precursor plasmids.

Dissociation of FN68 gave rise to different progeny in gene transfer experiments. In conjugational transfer of FN68 from JC5466 to Er. herbicola, $\mathrm{F}^{+} \mathrm{Carb}^{\mathrm{R}}$ progeny were obtained which did not carry his or nif, according to further transfer to c603. With K. pneumoniae, his and nif apparently separated from $\mathrm{Carb}^{\mathrm{R}}$ and were transferred at a higher frequency; with $S$. typhimurium a similar separation of determinants occurred but the relative transfer frequencies were reversed (Table 7). In transformation experiments with FN68 DNA prepared from SBI80r a rather similar separation occurred, but with plasmid DNA from JC 5466 
a new combination appeared regularly: the recipient $\mathrm{C}^{6} 63$ became $\mathrm{F}^{+} \mathrm{His}^{+} \mathrm{Nif}^{-}$(Table 7 ). These observations show that several marker combinations may result from dissociation of FN68; one of these separates F and Carb from Klebsiella his and nif, another splits the Klebsiella DNA so as to separate nif from $\mathrm{F}$ and his, the latter being together on a plasmid which transforms $\mathrm{C} 603$ particularly readily.

Translocation of carbenicillin resistance from a $\mathrm{P}$ plasmid to the $\mathrm{F}^{\prime}$ nif factor not only provided a useful selectable marker but also increased the stability of the Klebsiella determinants. The insertion of carbenicillin resistance into a plasmid should increase its molecular weight by I to 4 megadaltons (Hedges \& Jacob, 1974). We observed no difference in molecular weight estimated from sedimentation profiles of FN68 and FN39; our sucrose gradient technique was not sufficiently sensitive to detect such a small change in molecular weight. However, using FN68 DNA we obtained $\mathrm{His}^{+} \mathrm{Nif}^{+} \mathrm{Carb}^{\mathrm{k}}$ transformants of $K$. pneumoniae, indicating that all three determinants are located on the same molecule.

Although FN68 was used for transformation of E. coli and Klebsiella the frequency was low. This was due in part to the presence of chromosomal DNA in the preparation, and obviously the large size of the plasmid, making it readily degradable by mechanical shear, lowered the transformation frequency. The unwieldy size of FN68 made the large-scale isolation of purified and intact plasmid molecules, necessary for efficient transformation, practically impossible. The apparent component replicons of FN68 observed on sucrose gradients were present in amounts too small to allow preparative isolation.

An $\mathrm{F}^{\prime}$ nif factor should provide a useful genetic tool for the study of the nitrogen-fixation genes, their expression and their regulation, since all the mutants of $E$. coli which have become available to molecular biologists in the last two decades are now potential hosts for nif genes. The plasmids can be used for intergeneric transfer of nif, but the restricted host range of $F$, the large size of the plasmids and their tendency to dissociate limit their value for intergeneric nif transfer. In our hands, transfer and expression of his and nif on FN68 was limited to three out of five enteric genera tested: Klebsiella, E. coli and S. typhimurium.

Finally, we recognize that these studies provide only circumstantial evidence that the nif genes on the plasmids are in fact structural genes determining nitrogenase synthesis. It would be possible to interpret all our findings, and earlier conjugational nif gene transfers, if cryptic nif genes were present in the recipient Escherichia, Klebsiella and Salmonella species and if the plasmids carried only a regulatory determinant which allowed expression of cryptic nif. Though this is an unlikely prospect, a precedent for the existence of cryptic nif in microbes is presented by those strains of Rhizobium which do not fix nitrogen away from the host plant yet which have now been shown unequivocally to carry nif genes (Child, I975; Scowcroft \& Gibson, 1975). Experiments are being undertaken to demonstrate the presence of nif structural genes on these plasmids.

We thank Miss M. Warren-Wilson for help with construction of plasmid FN39, Dr J. Beringer for helpful discussion on the translocation procedures used in constructing FN68, Miss P. Harrison for excellent technical assistance and Dr R. L. Richards for the ${ }^{15} \mathrm{~N}_{2}$ determinations. 


\section{REFERENCES}

Bazaral, M. \& Helinski, D. R. (1968). Characterization of multiple circular DNA forms of colicincgenic factor EI from Proteus mirabilis. Biochemisiry 7, 35 I 3-35 19.

BERINGER, J. E. (1974). Transposition of carbenicillin resistance between plasmids in Escherichia coli. Heredity 33, 134 .

Blumenthal, T. (1972). Pi transduction: formation of heterogenotes upon cotransduction of bacterial genes with a $\mathrm{P} 2$ prophage. Virology $47,76-93$.

Cannon, F. C., Dixon, R. A., Postgate, J. R. \& Primrose, S. B. (i974a). Chromosomal integration of Klebsiella nitrogen fixation genes in Escherichia coli. Journal of General Microbiology, 8o, 227-239.

Cannon, F. C., Dixon, R. A., Postgate, J. R. \& Primrose, S. B. (1974 b). Plasmids formed in nitrogenfixing Escherichia coli-Klebsiella pneumoniae hybrids. Journal of General Microbiology 8o, 241-25I.

CHILD, J. J. (I975). Nitrogen fixation by a Rhizobium species in association with non legumincus plant cell cultures. Nature, London 253, 350-35I.

Clowes, R. C. (1972). Molecular structure of bacterial plasmids. Bacteriological Reviews 36, 361-405.

Conen, S. N., Chang, A. C. Y. \& Hsu, L. (1972). Nonchromosomal antibiotic resistance in bacteria: genetic transformation of Escherichia coli by R-factor DNA. Proceedings of the National Academy of Sciences of the United States of America 69, 2 I IO-2 1 I4.

Curtiss, R., Charamella, L. J., Stallions, D. R. \& Mays, J. A.. (i968). Parental functions during conjugation in Escherichia coli K-12. Bacteriological Reviews 32, 320-348.

Davis, B. D. \& Mingloli, E. S. (1950). Mutants of Escherichia coli requiring methionine or vitamin BI2. Journal of Bacteriology 6o, 17-28.

Dixon, R. A. (1974). Construction of an F-prime factor and derivative plasmids carrying the nitrogen fixation genes from Klebsiella pneumoniae. Heredity 33, 134-135.

Dixon, R. A., Canion, F. C. \& Postgate, J. R. (1975). Properties of the R-factor Ri44drd 3 in Klebsiella strain M5aI. Genetical Research 28, 327-338.

Dixon, R. A. \& Postgate, J. R. (1971). Transfer of nitrogen fixation genes by conjugation in Klebsiella pneumoniae. Nature, London 234, 47-48.

Dixon, R. A. \& Postage, J. R. ( I972). Genetic transfer of nitrogen fixation from Klebsiella pneumonicie to Escherichia coli. Nature, London 237, $102-103$.

Garric-Silversmith, L. \& Hartman, P. E. (19\%0). Histidine-requiring mutants of Escherichia coli K-I 2. Genetics 66, 23 I-244.

HedGes, R. W. \& JACOB, A. E. (1974). Transposition of ampicillin resistance from RP4 to other replicons. Molecular and General Genetics $\mathbf{1 3 2}, 3 \mathrm{I}-40$.

HiLl, S. (1973). A simple method for exposing bacterial cultures on solid media to a defined gas mixture using nylon bags. Laboratory Practice 22, 193.

Holloway, B. W. \& Richmond, M. W. (I 973). R-factors used for genetic studies in strains of Psendomonas aeruginosa and their origin. Genetical Research 21, 103-105.

Jobanputra, R. S. \& DatTA, N. (1974). Trimethoprim resistance factors in enterobacteria from clinical specimens. Journal of Medical Microbiology 7, 169-177.

Low, B. (1968). Formation of merodiploids in matings with a class of $\operatorname{Rec}^{-}$recipient strains of Escherichia coli K-12. Proceedings of the National Academy of Sciences of the United States of America 60, 160167.

Monk, M. \& Clowes, R. C. (1964). Transfer of colicin I factor in Escherichia coli K-I 2 and its interaction with the F fertility factor. Journal of General Microbiology 36, 365-384.

Oliver, D. R., Morris, J. J. \& Whitfield, H. J. (1974). Evidence for a ccmposite state of an $\mathrm{F}^{\prime} h i s$, gnd element and a cryptic plasmid in a derivative of Salmonella typhimurium LT2. Journal of Bacteriology II9, 192-201.

Peyru, G. \& Fraenkel, D. G. (1968). Genetic mapping of loci for glucose 6-phosphate dehydrogenase and glucose-6-phosphate dehydrase in Escherichia coli. Journal of Bacteriology 95, 1272-1278.

Pittard, J. \& Wallace, B. J. (1966). Genes controlling the uptake of shikimic acid by Escherichia coli. Journal of Bacteriology 92, 1070-1075.

Postgate, J. R. (1972). The acetylene reduction test for nitrogen fixation. In Methods in Microbiology, vol. 6b, pp. 343-356. Edited by J. R. Norris and D. W. Ribbons. London: Academic Press.

Postgate, J. R. ( (1974). Prerequisites of biological nitrogen fixation in free-living organisms. In Biological Nitrogen Fixation. Edited by A.. Quispel. Amsterdam: North Holland.

Scowcroft, W. R. \& Gibson, A. H. (1975). Nitrogen fixation by Rhizobium associated with tobacco and cowpea cell culture. Nature, London 253, 351-352.

Schildkraut, C. L., Marmur, J. \& Doty, P. (i962). Determination of the base composition of deoxyribonucleic acid from its buoyant density in CsCl. Journal of Molecular Biology 4, 430-443.

Shanmugam, K. T., Loo, A. S. \& Valentine, R. C. (1974). Deletion mutants of nitrogen fixation in Klebsiella pneumoniae mapping of a cluster of $n i j^{f}$ genes essential for nitrogenase activity. Biochemica et biophysica acta 338, 545-553. 
Streicher, S. L., Gurney, E. G. \& Valentine, R. C. (I97I). Transduction of the nitrogen fixation genes in Klebsiella pneumoniae. Proceedings of the National Academy of Sciences of the United States of America 68, II 74-II 77.

Streicher, S. L., Gurney, E. G. \& Valentine, R. C. (1972). The nitrogen fixation genes. Nature, London 239, 495-499.

TAYLOR, A. L. \& ADELBERG, E. A. (1960). Linkage analysis with very high frequency males of Escherichia coli. Genetics 45, 1233-1243.

TAYLOR, A. L. \& TrotTER, C. D. (1972). Linkage map of Escherichia coli strain K-I 2. Bacteriological Reviews $36,504-524$.

TuBB, R. S. (1974). Glutamine synthetase and ammonia regulation of nitrogenase synthesis in Klebsiella. Nature, London 251, 481-485.

VolL, M. J. (1972). Derivation of an F-merogenote and a $\phi 80$ high frequency transducing phage carrying the histidine operon of Salmonella. Journal of Bacteriology ro9, 74I-750.

Willetts, N. \& BastaRRACHEA, F. (1972). Genetic and physicochemical characterization of Escherichia coli strains carrying fused $\mathrm{F}^{\prime}$ elements derived from KLFI and F57. Froceedings of the National Academy of Sciences of the United States of America 69, I48I-I 485.

WilletTS, N. S., Clark, A. J. \& Low, B. (I969). Genetic location of certain mutations conferring recombination deficiency in Escherichia coli. Journal of Bacteriology 97, 244-249. 